\title{
Performance of Acid-Tolerant Soybean Promising Lines in Two Planting Seasons
}

\author{
Heru Kuswantoro ${ }^{1} \&$ Syahrul Zen ${ }^{2}$ \\ ${ }^{1}$ Indonesian Legume and Tuber Crops Research Institute, Indonesian Agency for Agricultural Research and \\ Development, Malang, Indonesia \\ 2 West Sumatera Assessment Institute for Agricultural Technology, Indonesian Agency for Agricultural \\ Research and Development, Solok, Indonesia \\ Correspondence: Heru Kuswantoro, Indonesian Legume and Tuber Crops Research Institute, Indonesian Agency \\ for Agricultural Research and Development, Malang, Indonesia. E-mail: herukusw@yahoo.com
}

Received: March 26, 2013 Accepted: April 25, 2013 Online Published: May 15, 2013

doi:10.5539/ijb.v5n3p49 URL: http://dx.doi.org/10.5539/ijb.v5n3p49

\begin{abstract}
Phenotypic performance of a genotype is not similar from season to season depends on the environment condition such as amount and time of water availability. Objective of this study was to identify soybean promising lines with high yield on acid soil in two planting seasons. The research was conducted in rainy season 2009 and 2010 at Sitiung Research Station, West Sumatera, Indonesia. The soil of the experimental field is Ultisols with $\mathrm{pH}\left(\mathrm{H}_{2} \mathrm{O}\right)$ 4.3, exchangeable-Al $3.92 \mathrm{me} / 100 \mathrm{~g}$, and $\mathrm{Al}$ saturation 56.48\%. The experiment was arranged in randomized completely block design with four replications. Result showed that the average of seed yield in RS 2010 was higher than that in RS 2009. Water supply was very important in pod filling period, plant height, filled pod, flowering and maturity days that may lead the seed yield performance. Based on the average of yield in two planting seasons, there were two genotypes having seed yield higher than the highest check variety, i.e. genotypes of SC5P2P3.23.4.1-3-28-3 and SC5P2P3.23.4.1-5. Therefore, these two genotypes are possibly to be released as new acid-tolerant varieties or can be served as new genetic materials for developing acid-tolerant variety.
\end{abstract}

Keywords: acid soil, flowering stage, soybean, yield

\section{Introduction}

Approximately $69 \%$ of dryland in Indonesia are acid soils (Mulyani, 2006), and an estimated 30-40\% of the world's total land area consists of acid soils (Haug, 1983; Uexkull \& Mutert, 1995). Many problems soil are found in these soils, and they can be divided into two groups i.e. micronutrient toxicity and macronutrient deficiency. However, of many problems soil, Al toxicity is the most important in acid soil and being a major constraint for crop production on $67 \%$ of the total acid area (Esawaran et al., 1997). Al toxicity causes hindering plant growth and development due to the inhibition of root elongation lead by the destroying cell structure of the root apex (Zheng, 2010).

For improving crops production, minerals toxicity can be ameliorated by surface application of lime, but this is not economically feasible for the poor farmers (Uguru et al., 2012). Hence, an alternative strategy should be provided for improving crops production on acid soils. A less costly complementary approach can be implemented by the improvement of the genetic Al resistance and it can be the most effective strategy for improving crop production on acid soils. Many research activities have been conducted to provide acid soil tolerance varieties from developing screening technique (Ferrufino et al., 2000), germplasm screening (Foy et al., 1992; Foy et al., 1993); inheritance (Kuswantoro et al., 2011), segregating population selection (Spehar \& Souza, 2006) and cultivars response (Board \& Caldwell, 1991).

Genotypic expression of a phenotype is environmentally dependent because gene expression is subject to modification by the environment (Kang, 1998). Therefore, under diverse agro-ecological conditions, phenotypic performance of a genotype is not necessarily the same (Ali et al., 2003). To ensure that selected genotypes have acceptable performance in variable environments within the target region, testing over diverse environment is very important (Ashraf et al., 2010). Planting season is one of the environment factors causing different 
genotypic expression of a specific genotype. Principally the weather condition at a planting season, especially rainfall, is a prime factor rather than soil type and fertility causing that phenomenon. Water deficit at flowering stage would affect soybean performance, and indicated by decreasing yield and yield components (Kobraee et al., 2011; Kobraee \& Shamsi, 2011a).

The objective of this study was to identify soybean promising lines that maintained high yields on acid soil in two planting seasons.

\section{Materials and Method}

Two experiments were conducted during rainy season of 2009 and 2010 at Sitiung Research Station, West Sumatera. Indonesia. Ten promising lines and two checks of acid-tolerant soybean varieties (Tanggamus and Wilis) were used in this study. Planting dates were September 3, 2009, and December 9, 2010. Soil type is Ultisols, and the soil properties are $\mathrm{pH}\left(\mathrm{H}_{2} \mathrm{O}\right) 4.3, \mathrm{P}_{2} \mathrm{O}_{5}$ (Bray II) 1.65 , Ca $1.09 \mathrm{me} / 100 \mathrm{~g}, \mathrm{Mg} 0.25 \mathrm{me} / 100 \mathrm{~g}, \mathrm{Na}$ $0.8 \mathrm{me} / 100 \mathrm{~g}, \mathrm{~K} 0.19 \mathrm{me} / 100 \mathrm{~g}$, CEC 6.94, Al dd 3.92, and Al saturation 56.48\%. The genotypes were arranged in a randomized completely block design with four replications. Each genotype was planted in 6 rows plot of 4.5 $\mathrm{m}$ long, planting space was $40 \mathrm{~cm} \times 15 \mathrm{~cm}$. Fertilizers were applied at rates equivalent to Urea:SP36:KCl $=$ 75:100:100 kg/ha.

In rainy season (RS) 2009 and 2010 the irrigation were applied by using the rainfall. The rainfalls in RS 2009 from September to December were 153.1, 53.0, 170.1 and $270.0 \mathrm{~mm}$; while in RS 2010 from January to April were 193.6, 186.1, 283.2, $121.9 \mathrm{~mm}$ (Table 1). From each genotype in all of the four replications, observations were recorded on ten randomly selected plants for plant height $(\mathrm{cm})$ and filled pods per plant; while observation were recorded on plot for days to $50 \%$ flowering, days to maturity and seed yield (t/ha). The data were statistically analyzed using analysis of variance and continued with least significant difference (LSD) for mean comparison.

Table 1. Distribution of rainfall in two planting seasons, RS 2009 and RS 2010

\begin{tabular}{ll}
\hline Month & Rainfall $(\mathrm{mm})$ \\
\hline September 2009 & 153.1 \\
October 2009 & 53 \\
November 2009 & 170.1 \\
December 2009 & 270 \\
January 2010 & 193.3 \\
February 2010 & 186.1 \\
March 2010 & 283.2 \\
April 2010 & 121.9 \\
\hline
\end{tabular}

\section{Results and Discussion}

Analysis of variance showed that genetic $x$ environment (GE) interaction of all of observed characters were significant, except seed yield (Table 2). It is suggested that there was no ranking change for seed yield performance if the genotypes grown in rainy season 2009 and rainy season 2010 in that area. This made genotypes selection was easier compare to that in the present of GE interaction; as stated by Uguru et al. (2012) that only in the absence of GE interaction, crop performance across environments was a useful indicator of genotypic performance.

Average seed yield in RS 2010 was higher than that of RS 2009 (Table 3). The different rainfalls during the two planting seasons (Table 1) affected water supply for the soybean growth and development, where the soybeans encountered drought stress on flowering stage in RS 2009. It caused plants in lower water supply having lower seed yield (Daneshian et al., 2011; Kobraee et al., 2011). Related study also reported by Demirtas et al. (2010) where drought stress significantly affected seed yield. Dry matter production was restricted by soil moisture before flowering period causing stronger effect after flowering (Oya et al., 2004). Further, Oya et al. (2004) found significant correlation between seed yield and crop growth rate during the drought stress period at early reproductive growth; and stated that a key for high seed yield under drought condition was the maintenance of a 
high crop growth rate during drought stress period. In this research, significant correlations between yield and filled pods were found on both of RS 2009 and RS 2010 (Table 6).

Table 2. Analysis of variance of soybean promising lines and the check varieties in two planting seasons. RS 2009 and RS 2010

\begin{tabular}{lllllll}
\hline Source & Df & Yield & Height & Pod-f & Flower & Maturity \\
\hline E (season) & 1 & $24.39^{* *}$ & $15.611^{* *}$ & $148.04^{* *}$ & $4.095^{* *}$ & $276.76^{* *}$ \\
Rep*E & 6 & $0.61^{* *}$ & $196.06^{* *}$ & $481.98^{* *}$ & $5.33^{* *}$ & $3.29 \mathrm{~ns}$ \\
G (genotype) & 11 & $0.32^{* *}$ & $81.31^{* *}$ & $401.73^{* *}$ & $19.71^{* *}$ & $85.85^{* *}$ \\
G*E & 11 & $0.16 \mathrm{~ns}$ & $89.00^{* *}$ & $214.24^{* *}$ & $11.25^{* *}$ & $12.58^{* *}$ \\
Error & 66 & 0.12 & 18.41 & 33.06 & 1.19 & 4.33 \\
\hline CV (\%) & & 19.85 & 8.31 & 7.62 & 3.42 & 2.50
\end{tabular}

ns $=$ non significant, $* *=$ significant at $0.01 \%$, Yield $=$ seed yield per plot $(\mathrm{t} / \mathrm{ha})$, Height $=$ plant height $(\mathrm{cm})$, Pod-f $=$ filled pods per plant, Flower $=$ days to $50 \%$ flowering, Maturity $=$ days to maturity.

In RS 2010 genotype SC5P2P3.5.4.1.5 had the highest seed yield followed by genotype of SC5P2P3.23.4.1-3-28-3 and the check variety of Wilis, while in RS 2009 there were no differences among genotypes (Table 3). Based on the average of the two seasons, there were two genotypes having seed yield higher than the highest check variety, i.e. genotypes of SC5P2P3.23.4.1-3-28-3 and SC5P2P3.23.4.1-5. Some researchers also reported similar results that responses of soybean genotypes to water deficit stress lowering seed yield (Daneshian et al., 2011; Kosturkova et al., 2008; Oya et al., 2004).

Table 3. Seed yield of soybean promising lines and the check varieties in two planting seasons, RS 2009 and RS 2010

\begin{tabular}{llll}
\hline \multirow{2}{*}{ Genotypes } & \multicolumn{3}{c}{ Yield (t/ha) } \\
\cline { 2 - 4 } & RS 2009 & RS 2010 & Average \\
\hline SC2P2.99.5.4.5-1-6-1 & $1.21 \mathrm{ab}$ & $1.64 \mathrm{~d}$ & $1.42 \mathrm{~d}$ \\
SC2P2.151.3.5.1-10 & $1.30 \mathrm{ab}$ & $2.25 \mathrm{a}-\mathrm{c}$ & $1.77 \mathrm{a}-\mathrm{c}$ \\
SC5P2P3.23.4.1-3-28-3 & $1.51 \mathrm{a}$ & $2.46 \mathrm{a}$ & $1.99 \mathrm{a}$ \\
SC5P2P3.5.4.1.5 & $1.25 \mathrm{ab}$ & $2.51 \mathrm{a}$ & $1.88 \mathrm{ab}$ \\
SC5P2P3.23.4.1-5 & $1.54 \mathrm{a}$ & $2.44 \mathrm{a}$ & $1.99 \mathrm{a}$ \\
MLGG 0758 & $0.99 \mathrm{~b}$ & $2.40 \mathrm{ab}$ & $1.70 \mathrm{a}-\mathrm{d}$ \\
SJ-5/Msr.99.5.4.5-1-6-1 & $1.08 \mathrm{ab}$ & $2.15 \mathrm{a}-\mathrm{c}$ & $1.61 \mathrm{~b}-\mathrm{d}$ \\
Msr/SJ-5.21.3.7-3-27-1 & $1.26 \mathrm{ab}$ & $2.05 \mathrm{a}-\mathrm{d}$ & $1.66 \mathrm{a}-\mathrm{d}$ \\
Msr/SJ-5.23.4.1-3-28-3 & $0.97 \mathrm{~b}$ & $1.83 \mathrm{~cd}$ & $1.40 \mathrm{~d}$ \\
Msr/SJ-5.23.4.1-5 & $0.99 \mathrm{~b}$ & $2.42 \mathrm{ab}$ & $1.70 \mathrm{a}-\mathrm{d}$ \\
Tanggamus & $1.10 \mathrm{ab}$ & $1.95 \mathrm{~b}-\mathrm{d}$ & $1.53 \mathrm{~cd}$ \\
Wilis & $1.27 \mathrm{ab}$ & $2.47 \mathrm{a}$ & $1.87 \mathrm{ab}$ \\
\hline Average & $1.20 \mathrm{~b}$ & $2.21 \mathrm{a}$ & 1.705 \\
\hline
\end{tabular}

Number in the same column and followed by the same letter was not significantly different at LSD 5\%.

Plant height among soybean genotypes in RS 2009 and in RS 2010 had the differences among the genotypes (Table 4). The highest plant height was shown by both of Msr/SJ-5.21.3.7-3-27-1 and Msr/SJ-5.23.4.1-5 genotypes in RS 2010. Tanggamus as a check variety had the lowest plant height in RS 2009. Plant height average in RS 2009 was lower than that in RS 2010. Water deficit lead the plant height lower than in optimal condition (Demirtas et al., 2010; Zhang et al., 2011). 
Table 4. Plant height of soybean promising lines and two check varieties in two planting seasons. RS 2009 and RS 2010

\begin{tabular}{lll}
\hline \multirow{2}{*}{ Genotypes } & \multicolumn{2}{c}{ Plant height $(\mathrm{cm})$} \\
\cline { 2 - 3 } & RS 2009 & RS 2010 \\
\hline SC2P2.99.5.4.5-1-6-1 & $45.60 \mathrm{f}$ & $59.90 \mathrm{de}$ \\
SC2P2.151.3.5.1-10 & $43.05 \mathrm{fg}$ & $65.60 \mathrm{~b}-\mathrm{d}$ \\
SC5P2P3.23.4.1-3-28-3 & $39.10 \mathrm{gh}$ & $57.90 \mathrm{e}$ \\
SC5P2P3.5.4.1.5 & $38.95 \mathrm{gh}$ & $64.80 \mathrm{~b}-\mathrm{d}$ \\
SC5P2P3.23.4.1-5 & $37.30 \mathrm{gh}$ & $54.50 \mathrm{e}$ \\
MLGG 0758 & $37.35 \mathrm{gh}$ & $68.45 \mathrm{ab}$ \\
SJ-/Msr.99.5.4.5-1-6-1 & $37.55 \mathrm{gh}$ & $66.20 \mathrm{bc}$ \\
Msr/SJ-5.21.3.7-3-27-1 & $38.90 \mathrm{gh}$ & $73.15 \mathrm{a}$ \\
Msr/SJ-5.23.4.1-3-28-3 & $37.15 \mathrm{gh}$ & $60.30 \mathrm{c}-\mathrm{e}$ \\
Msr/SJ-5.23.4.1-5 & $38.00 \mathrm{gh}$ & $72.90 \mathrm{a}$ \\
Tanggamus & $35.75 \mathrm{~h}$ & $60.20 \mathrm{c}-\mathrm{e}$ \\
Wilis & $38.00 \mathrm{gh}$ & $68.85 \mathrm{ab}$ \\
\hline Average & $38.9 \mathrm{~b}$ & $64.4 \mathrm{a}$ \\
\hline
\end{tabular}

Number followed by the same letter was not significantly different at LSD 5\%.

Table 5. Filled pods characters of soybean promising lines and check varieties in two planting seasons, RS 2009 and RS 2010

\begin{tabular}{lll}
\hline \multirow{2}{*}{ Genotypes } & \multicolumn{2}{c}{ Number of filled pod/plant } \\
\cline { 2 - 3 } & RS 2009 & RS 2010 \\
\hline SC2P2.99.5.4.5-1-6-1 & $45.05 \mathrm{~h}$ & $103.65 \mathrm{e}-\mathrm{g}$ \\
SC2P2.151.3.5.1-10 & $33.45 \mathrm{j}-\mathrm{m}$ & $121.50 \mathrm{a}-\mathrm{c}$ \\
SC5P2P3.23.4.1-3-28-3 & $45.75 \mathrm{~h}$ & $116.15 \mathrm{~cd}$ \\
SC5P2P3.5.4.1.5 & $40.10 \mathrm{~h}-\mathrm{j}$ & $122.10 \mathrm{a}-\mathrm{c}$ \\
SC5P2P3.23.4.1-5 & $42.25 \mathrm{hi}$ & $127.95 \mathrm{a}$ \\
MLGG 0758 & $29.60 \mathrm{~lm}$ & $119.30 \mathrm{bc}$ \\
SJ-/Msr.99.5.4.5-1-6-1 & $31.20 \mathrm{k}-\mathrm{m}$ & $105.50 \mathrm{ef}$ \\
Msr/SJ-5.21.3.7-3-27-1 & $35.85 \mathrm{i}-1$ & $101.50 \mathrm{fg}$ \\
Msr/SJ-5.23.4.1-3-28-3 & $25.80 \mathrm{~m}$ & $96.95 \mathrm{~g}$ \\
Msr/SJ-5.23.4.1-5 & $29.75 \mathrm{~lm}$ & $111.13 \mathrm{de}$ \\
Tanggamus & $36.25 \mathrm{i}-1$ & $127.10 \mathrm{ab}$ \\
Wilis & $38.80 \mathrm{~h}-\mathrm{k}$ & $123.50 \mathrm{a}-\mathrm{c}$ \\
\hline Average & $36.2 \mathrm{~b}$ & $114.7 \mathrm{a}$ \\
\hline
\end{tabular}

Number followed by the same letter was not significantly different at LSD 5\%.

Filled pod is the main yield component that supported the yield. In RS 2009, the highest filled pods was achieved by SC5P2P3.23.4.1-3-28-3 (Table 5). This genotype consistently produced high filled pods up to 116 pods in RS 2010. The lowest genotype Msr/SJ-5.23.4.1-3-28-3 in RS 2009 also consistently had the lowest filled pods in RS 2010. However, the check varieties i.e. Tanggamus and Wilis, having 36 and 38 filled pods respectively in RS 2009, showed the highest filled pods up to 127 and 123 pods as many as genotype of SC5P2P3.23.4.1-5 with 128 filled pods. Drought induced pod abortion during the critical pod development, where the critical stage for 
pod abortion was 3-5 days after anthesis and severe drought stress significantly decreased pod set up to 40\% (Liu, 2004). The number of pods was largely dependent on the number of floral buds that initiate pods (Desclaux et al., 2000).

Days to flowering was determined when the $50 \%$ plants in a plot were flowering. Days to flowering in RS 2009 were similar among the genotypes, while in RS 2010 days to flowering were vary and longer than that in RS 2009 (Table 6). Tanggamus had the highest days to flowering in both planting seasons (27 days in RS 2009 and 42 days in RS 2010). Flowering stage is one of the most sensitive growth stages (Kobraee \& Shamsi, 2011a). In RS 2009, there was no rainfall up to 9 days before flowering date and 15 days after flowering date (data not shown). It shortened flowering date than when the genotypes were cultivated in relatively optimal condition in RS 2010. The water supply in this stage had an extreme effect on pod per plant and finally it effected on seed yield (Demirtas et al., 2010; Kobraee \& Shamsi, 2011b). In this study, although the seed filling period was longer under water deficit in RS 2009 than in RS 2010 due to the shortening of flowering stage affected by the water deficit, the production was lower due to the flower abortion (Liu et al., 2003). Hamayun et al. (2010) stated that drought stress at pre and post flowering stage significantly affected to soybean growth and yield attributes.

Table 6 . Days to $50 \%$ flowering and days to maturity of soybean promising lines and two check varieties in two planting seasons. RS 2009 and RS 2010

\begin{tabular}{lllll}
\hline \multirow{2}{*}{ Genotypes } & \multicolumn{2}{c}{ Days to flowering (day) } & \multicolumn{2}{c}{ Days to maturity (day) } \\
\cline { 2 - 5 } & RS 2009 & RS 2010 & RS 2009 & RS 2010 \\
\hline SC2P2.99.5.4.5-1-6-1 & $25.50 \mathrm{fg}$ & $43.50 \mathrm{a}$ & $87.50 \mathrm{ab}$ & $89.50 \mathrm{a}$ \\
SC2P2.151.3.5.1-10 & $25.00 \mathrm{fg}$ & $37.50 \mathrm{~b}-\mathrm{d}$ & $80.25 \mathrm{fg}$ & $84.50 \mathrm{c}-\mathrm{e}$ \\
SC5P2P3.23.4.1-3-28-3 & $25.00 \mathrm{fg}$ & $38.00 \mathrm{bc}$ & $80.25 \mathrm{fg}$ & $84.75 \mathrm{~b}-\mathrm{e}$ \\
SC5P2P3.5.4.1.5 & $24.75 \mathrm{fg}$ & $37.25 \mathrm{~cd}$ & $83.00 \mathrm{ef}$ & $84.00 \mathrm{c}-\mathrm{e}$ \\
SC5P2P3.23.4.1-5 & $25.25 \mathrm{fg}$ & $38.50 \mathrm{bc}$ & $83.00 \mathrm{ef}$ & $84.00 \mathrm{c}-\mathrm{e}$ \\
MLGG 0758 & $24.75 \mathrm{fg}$ & $33 \mathrm{e}$ & $77.50 \mathrm{~g}$ & $78.75 \mathrm{~g}$ \\
SJ-/Msr.99.5.4.5-1-6-1 & $25.50 \mathrm{fg}$ & $38.75 \mathrm{bc}$ & $83.00 \mathrm{ef}$ & $89.50 \mathrm{a}$ \\
Msr/SJ-5.21.3.7-3-27-1 & $24.25 \mathrm{~g}$ & $38.50 \mathrm{bc}$ & $78.25 \mathrm{~g}$ & $85.00 \mathrm{~b}-\mathrm{e}$ \\
Msr/SJ-5.23.4.1-3-28-3 & $24.75 \mathrm{fg}$ & $38.00 \mathrm{bc}$ & $79.00 \mathrm{~g}$ & $86.00 \mathrm{~b}-\mathrm{d}$ \\
Msr/SJ-5.23.4.1-5 & $24.75 \mathrm{fg}$ & $39.00 \mathrm{~b}$ & $80.25 \mathrm{fg}$ & $83.50 \mathrm{de}$ \\
Tanggamus & $27.75 \mathrm{e}$ & $42.00 \mathrm{a}$ & $86.50 \mathrm{bc}$ & $90.25 \mathrm{a}$ \\
Wilis & $26.25 \mathrm{ef}$ & $36.25 \mathrm{~d}$ & $78.75 \mathrm{~g}$ & $78.25 \mathrm{~g}$ \\
\hline Average & $25.3 \mathrm{~b}$ & $38.4 \mathrm{a}$ & $81.4 \mathrm{~b}$ & $84.8 \mathrm{a}$ \\
\hline
\end{tabular}

Number followed by the same letter was not significantly different at LSD 5\%.

Genotypes of MLGG 0758 and Wilis had lowest days to maturity than other genotypes in RS 2009 and RS 2010. In both planting seasons, the highest maturity was showed by SC2P2.99.5.4.5-1-6-1 and Tanggamus. However, in RS 2010 SJ-/Msr.99.5.4.5-1-6-1 also showed the longest maturity. The lower water supply in RS 2009 caused lower maturity than RS 2010. It was caused by phenologycal avoiding as a drought tolerance mechanism. Similar result also reported by Acosta-Diaz et al. (2009) that drought treatment reduced days to maturity. Increasing relative maturity lead plant height increased (Shonjani, 2002).

Significant positive correlation found on yield and filled pod in both of RS 2009 and 2010, and on flowering and maturity in RS 2010 (Table 7). It suggested that performance of seed yield was supported by yield components such as plant height, numbers of filled pods, and both of flowering and maturity days. However, relationship among these components has shown to be inconsistent (De Bruin \& Pedersen, 2009). On another hand, significant negative correlation was found on yield and both of flowering and maturity in RS 2010. It suggested that in these genotypes the longevity of flowering and maturity will decrease seed yield. 
Table 7. Relationship of yield and yield components of soybean promising lines and the check varieties in two planting seasons, RS 2009 and RS 2010

\begin{tabular}{lllll}
\hline & Flower & Maturity & Height & Pod-f \\
\hline Yield & -0.036 & 0.108 & 0.227 & $0.810^{* *}$ \\
& $-0.677^{*}$ & $-0.696^{*}$ & 0.199 & $0.613^{*}$ \\
Flower & & 0.571 & -0.229 & 0.185 \\
& & $0.841^{* *}$ & -0.359 & -0.225 \\
Maturity & & 0.297 & 0.471 \\
& & & -0.389 & -0.341 \\
Height & & & 0.405 \\
& & & -0.237
\end{tabular}

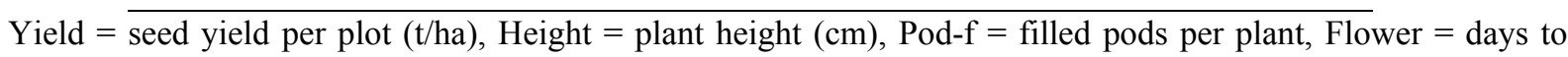
$50 \%$ flowering, Maturity $=$ days to maturity. Upper $=$ RS 2009, Lower $=$ RS 2010.

\section{Conclusion}

In two planting seasons, water stressed and unstressed at flowering stage lead the lower average of seed yield in RS 2009 than in RS 2010. The water stressed at flowering stage condition in RS 2009 also lead similar flowering day among the genotypes in RS 2009, while the unstressed flowering stage in RS 2010 lead the days to flowering varied and longer. Even though the days to flowering were similar in RS 2009, the days to maturity varied in both of the two seasons. Genotypes MLGG 0758 and Wilis had earliest days to maturity than the other genotypes in RS 2009 and RS 2010. In two planting seasons, the longest maturity was showed by SC2P2.99.5.4.5-1-6-1 and Tanggamus. There were two genotypes having seed yield higher than the highest check variety in two planting seasons, i.e. SC5P2P3.23.4.1-3-28-3 and SC5P2P3.23.4.1-5. These two genotypes need to be tested under diverse acid soil areas to be released as new acid-tolerant varieties or can be served as new genetic materials for developing acid-tolerant variety.

\section{Acknowledgements}

This study was funded by the State Ministry of Research and Technology of Indonesia through SINTA Project 2009. Thank to Mr. Zarwan and Mr. Erdiman for the assistance in research activities.

\section{References}

Acosta-Díaz, E., Acosta-Gallegos, J. A., Trejo-López, C., Padilla-Ramírez, J. S., \& Amador-Ramírez, M. D. (2009). Adaptation traits in dry bean cultivars grown under drought stress. Agricultura Técnica en México, $35,416-425$.

Ali, N., Javidfar, F., \& Mirza, Y. (2003). Selection of stable rapeseed (Brassica napus L.) genotypes through regression analysis. Pak. J. Bot., 35, 175-183.

Ashraf, M., Iqbal, Z., Arshad, M., Waheed, A., Glufran, M. A., Chaudhry, Z., \& Baig, D. (2010). Multi-environment response in seed yield of soybean [Glycine max (L.) Merrill], genotypes through GGE biplot technique. Pak. J. Bot., 42, 3899-3905.

Board, J. E., \& Caldwell, A. G. (1991). Response of determinate soybean cultivars to low pH soils. Plant and Soil, 132, 289-292. http://dx.doi.org/10.1007/BF00010410

Daneshian, J., Jonoubi, P., \& Barari-Tari, D. (2011). Investigation of Water Deficit Stress on Agronomical Traits of Soybean Cultivars in Temperate Climate. World Academy of Science, Engineering and Technology, 75, 778-785.

De Bruin, J. L., \& Pedersen, P. (2009). Growth, yield, and yield component changes among old and new soybean cultivars. Agron. J., 101, 124-130. http://dx.doi.org/10.2134/agronj2008.0187

Demirtas, C., Yazgan, S., Candogan, B. N., Sincik, M., Büyükcangaz, H., \& Göksoy, A. T. (2010). Quality and yield response of soybean (Glycine max L. Merrill) to drought stress in sub-humid environment. African Journal of Biotechnology, 9, 6873-6881. 
Desclaux, D., Huynh, T. T., \& Roumet, P. (2000). Identification of soybean plant characteristics that indicate the timing of drought stress. Crop Sci., 40, 716-722. http://dx.doi.org/10.2135/cropsci2000.403716x

Esawaran, H., Reich, P. F., \& Beinroth, F. H. (1997). Global distribution of soils with acidity. In A. Z. Moniz, A. M. C. Furlani, R. E. Schaffert, N. K. Fageria, C. A. Rosolem, \& H. Cantarella (Eds.), Plant-Soil Interactions at Low pH: Sustainable Agriculture and Forestry Production. Proceedings of the 4th International Symposium on Plant-Soil Interactions at Low Ph (pp. 159-164). Belo Horizonte, Minas Gerais, Brazil.

Ferrufino, A., Smyth, T. J. Israel, D. W., \& Carter, T. E. (2000). Root elongation of soybean genotypes in response to acidity constraints in a subsurface solution compartment. Crop Sci., 40, 413-421. http://dx.doi.org/10.2135/cropsci2000.402413x

Foy, C. D., Duke, J. A., \& Devine, T. E. (1992). Tolerance of soybean germplasm to an acid Tatum subsoil. Journal of Plant Nutrition, 15, 527-547. http://dx.doi.org/10.1080/01904169209364339

Foy, C. D., Shalunova, L. P., \& Lee, E. H. (1993). Acid soil tolerance of soybean (Glycine max L. Merr.) germplasm from the USSR. Journal of Plant Nutrition, 16, 1593-1617. http://dx.doi.org/10.1080/01904169309364636

Hamayun, M., Khan, S. A., Shinwari, Z. K., Khan, A. K., Ahmad, N., \& Lee, I. J. (2010). Effect of polyethylene glycol induced drought stress on physio-hormonal attributes of soybean. Pak. J. Bot., 42, 977-986.

Haug, A. (1983). Molecular aspects of aluminum toxicity. CRC Crit. Rev. Plant. Sci., 1, 345-373.

Kang, M. S. (1998). Using genotype-by-environment interaction for crop cultivar development. Adv. Agron., 35, 199-240.

Kobraee, S., \& Shamsi, K. (2011a). Effect of Irrigation Regimes on Quantitative Traits of Soybean (Glycine max L.). Asian J. Exp. Biol. Sci., 2, 441-448.

Kobraee, S., \& Shamsi, K. (2011b). Evaluation of soybean yield under drought stress by path analysis. Australian Journal of Basic and Applied Sci., 5, 890-895.

Kobraee, S., Shamsi, K., \& Rasekhi, B. (2011). Soybean production under water deficit conditions. Annals of Biological Research, 2, 423-434.

Kosturkova, G., Todorova, R., Sakthivelu, G., Akitha-Devi, M. K., Giridhar, P., Rajasekaran, T., \& Ravishankar, G. A. (2008). Response of Bulgarian and Indian soybean genotypes to drought and water deficiency in field and laboratory conditions. Gen. Appl. Plant Physiol., 34, 239-250.

Kuswantoro, H., Basuki, N., \& Arsyad, D. M. (2011). Inheritance of soybean pod number trait on acid soil. Agrivita, 33, 119-126.

Liu, F. (2004). Physiological Regulation of Pod Set in Soybean (Glycine max L. Merr.) During Drought at Early Reproductive Stages. Department of Agricultural Sciences. The Royal Veterinary and Agricultural University. Copenhagen. Dissertation.

Liu, F., Andersen, M. N., \& Jensen, C. R. (2003). Loss of pod set caused by drought stress is associated with water status and ABA content of reproductive structures in soybean. Funct. Plant Biol., 30, http://dx.doi.org/271-280. 10.1071/FP02185

Mulyani, A. (2006). Potensi Lahan Kering Masam untuk Pengembangan Pertanian. Warta Penelitian dan Pengembangan Pertanian, 28, 16-17.

Oya, T., Nepomuceno, A. L., Neumaier, N., Farias, J. R. B., Tobita, S., \& Ito, O. (2004). Drought tolerance characteristics of Brazilian soybean cultivar: evaluation and characterization of drought tolerance of various Brazilian soybean cultivars in the field. Plant Prod. Sci., 7, 129-137. http://dx.doi.org/10.1626/pps.7.129

Shonjani, S. (2002). Salt Sensitivity of Rice, Maize, Sugar Beet, and Cotton During Germination and Early Vegetative Growth. Institute of Plant Nutrition. Justus Liebig University Giessen. Inaugural Dissertation.

Spehar, C. R., \& Souza, L. A. C. (2006). Selection for aluminum tolerance in tropical soybeans. Pesquisa Agropecuária Tropical, 36, 1-6.

Uexkull, von, H. R., \& Mutert, E. (1995). Global extent, development and economic impact of acid soils. In R. A. Date, N. J. Grundon, G. E. Raymet \& M. E. Probert (Eds.), Plant-Soil Interactions at Low pH: Principles and Management (pp. 5-9). Dordrecht, the Netherlands: Kluwer Academic Publishers. 
Uguru, M. I., Oyiga, B. C., \& Jandong, E. A. (2012). Responses of some soybean genotypes to different soil pH regimes in two planting seasons. The African Journal of Plant Science and Biotechnology, 6, 26-37.

Zhang, J, Smith, D. L. Liu, W., Chen, X., \& Yang, W. (2011). Effects of shade and drought stress on soybean hormones and yield of main-stem and branch. African Journal of Biotechnology, 10, 14392-14398. http://dx.doi.org/10.5897/AJB11.2143

Zheng, S. J. (2010). Crop production on acidic soils: overcoming aluminium toxicity and phosphorus deficiency. Annals of Botany, 106, 183-184. http://dx.doi.org/10.1093/aob/mcq134 